\title{
The Financial Meltdown of 2008: The Perspective of Jewish Law
}

Hershey H. Friedman, Ph.D.

Professor of Business and Marketing

Department of Economics

Brooklyn College

The City University of New York

E-mail: x.friedman@att.net
Linda W. Friedman, Ph.D.

Professor of Computer Information Systems

Department of Statistics and CIS

Baruch College Zicklin School of Business

and the Graduate School, CUNY

E-mail: Linda.Friedman@baruch.cuny.edu

\begin{abstract}
One of the great ironies of the financial meltdown of 2008 - which was really more of a values meltdown - is that very few U.S. laws were actually broken. This paper investigates the financial crisis from a different legal perspective - that of Jewish law, using six framing principles: misleading with bad advice; deception and fraud; bribery, both outright and subtle; honest weights and measures; conflicts of interest; and transparency. Each of these is used as a lens through which to view the activities and behaviors that caused the current financial debacle and, in the process, almost totaled the global economy. The paper concludes that Jewish law was violated at every step of the way towards the current financial catastrophe. Had the bankers, auditors, rating agencies, politicians, regulators, and mortgage brokers followed the principles of business ethics described in Jewish law, the global financial crisis would not have occurred.
\end{abstract}




\section{THE FINANCIAL MELTDOWN: THE PERSPECTIVE OF JEWISH LAW}

The financial meltdown has caused, so far, the loss of 30 to 50 million jobs worldwide and trillions of dollars in assets (Goodspeed, 2009). What is ironic about this financial crisis is that much of what transpired was actually legal under American law. The purpose of this paper is to investigate the financial crisis from the perspective of Jewish law, and in the process to construct a framework through which to accomplish this goal. Our investigation included both the ancient sources of Jewish law described in the next section, and more modern scholarship. For general overviews of Jewish business ethics, the interested reader is directed to, e.g., Friedman (1985), Levine (1987), Pava (1997), and Tamari (1991).

\section{SOURCES OF JEWISH LAW}

The Hebrew Bible, particularly the Pentateuch (i.e., the Torah), is replete with precepts that deal with business ethics. Just as the Hebrew Bible is the written law, the Talmud, a compilation of Jewish oral law, expounds on the Hebrew Bible and consists of the Mishna and Gemara. The Mishna, originally an ancient oral tradition, was compiled and edited in written form about 1800 years ago by Rabbi Judah the Nasi (President of the Sanhedrin). The Gemara, completed about 1500 years ago, consists mainly of commentaries on the Mishna. Two academies, in Israel and Babylon, independently studied the Mishna. Thus, there are two versions of the Talmud: the Jerusalem Talmud, a product of the academies in Israel, and the Babylonian Talmud, a product 
of the academies in Babylon. The Babylonian Talmud is considerably larger than the Jerusalem Talmud and more authoritative. The Talmud is mainly concerned with halacha (Jewish law) but also provides a detailed record of the beliefs of the Jewish people, their philosophy, traditions, culture, and folklore, i.e., the aggadah (homiletics).

The Midrash, a separate scripture, recorded the views of the Talmudic sages and is mainly devoted to the exposition of Biblical verses. In addition, Maimonides and Joseph Caro were the authors of the two most important codes of Jewish law; they are based on discussions and debates regarding the law in the Talmud.

In order to encourage people to follow higher standards of ethics, the Talmud provides cases of individuals who behaved in exemplary ways, especially in difficult situations involving ethical dilemmas, often going beyond the requirements of the law (Friedman, 1985).

\section{FRAMING PRINCIPLES}

In our review of relevant halachic principles, a distinct few emerged as ideal in framing this discussion: misleading with bad advice; deception and fraud; bribery, both outright and subtle; honest weights and measures; conflicts of interest; and, finally, transparency. In the following sections we attempt to take each of these in turn and use it as a lens through which to view the activities and behaviors that caused the financial debacle of 2008 and, in the process, almost totaled the world economy. 


\section{MISLEADING OTHERS WITH BAD ADVICE}

The principle of lifnei iver (literally, "before the blind") prohibits one from giving bad advice to another person. It is based on the verse in the Hebrew Bible (Leviticus 19:14): "You shall not curse the deaf nor place a stumbling block before the blind; you shall fear your God - I am your Lord." The original Hebrew reads, lifnei iver lo sitten michshol ("before the blind do not place a stumbling block") and is often referred to, succinctly, as lifnei iver. The term "blind" is interpreted metaphorically as meaning someone who is unsuspecting, naïve, ignorant, or even morally blind. Thus, one who purposely gives bad advice to another has violated this law. In fact, one who conceals his true motives for giving the advice (e.g., there is a conflict of interest and the advisor stands to make a hidden profit or get a kickback from his advice) has violated the principle of lifnei iver (Midrash Sifra, Leviticus 19:14). As the Midrash explains, the reason the verse ends with the warning about fearing God is that human beings do not know whether advice proffered to them by friends is good or bad; after all, advice is often given with an ulterior motive. Only God knows the true motive of the advice giver. In addition, lifnei iver is considered to be a prohibition against helping or causing another to sin. Thus, placing any kind of prohibited temptation in front of someone would not be allowed. For example, providing an individual with a prohibited food would be a violation of lifnei iver (Babylonian Talmud, Pesachim 22b).

During the housing bubble that preceded the financial meltdown of 2008, individuals with very little income were able to purchase homes they could not afford. There are stories told of 
individuals with annual incomes of $\$ 14,000$ purchasing $\$ 750,000$ homes with no money down and no mortgage payments. Many mortgage brokers, acting in their own self interest, were advising these individuals to take on these mortgages and not to worry. Mortgage brokers are supposed to be impartial advisors who do their best to find good deals for clients needing a mortgage to purchase a home. Unfortunately, many mortgage brokers steered their clients toward extremely risky loans - mortgages their clients would never be able to repay - in order to earn very substantial fees and kickbacks. Most of these mortgages required very little money down (some required nothing down) but included ballooning expenses down the road (e.g., option Adjustable Rate Mortgages ARMs). These mortgage brokers - and the banks that arranged the loans - recognized that there was a good chance that the property owners would not be able to repay the loans once the interest rate was readjusted. There is no doubt that the banks and mortgage bankers knew exactly what they were doing. We know this because we now know what they themselves called these subprime mortgages: "NINJA loans" referred to mortgages given to people with "No Income, No Job or Assets"; "Liar loans" were those given to individuals who clearly were making outrageous claims about their income but it did not matter since no one was going to check; and "Stretch loans" were made to people who would have to use more than $50 \%$ of their monthly income to make the mortgage payments.

Mortgage brokers who counseled poor people to take on mortgages that they would have no way of repaying a few years down the road, and - because of their own greed - not even warning customers of the potential dangers, were clearly violating the principle of lifnei iver. Moreover, in advising someone to take on a mortgage that he or she cannot repay in the future the mortgage 
broker is causing them to sin, since not repaying loans is also a violation of the law. Thus, these types of mortgage loans (predatory mortgages) are a violation of the principle of lifnei iver.

\section{DECEPTION AND FRAUD}

Maimonides wrote one of the major codes of Jewish law, Mishneh Torah, in which he makes it clear that it is absolutely prohibited to deceive any person when buying or selling. Indeed, the seller is obligated to reveal to the prospective buyer any defects in the product under consideration. Maimonides emphasizes that geneivat da'at is prohibited (Mishneh Torah, Laws of Selling 18:1).

Geneivat da'at (literally, theft of thought) is the term used in Jewish law to indicate deception, cheating, creating a false impression, or acquiring undeserved goodwill. It is a theft of one's mind, thoughts, wisdom, or knowledge, i.e., fooling someone and thereby causing him or her to have a mistaken assumption, belief, and/or impression. Geneivat da'at goes beyond lying. Any words or actions that cause others to form incorrect conclusions about one's motives may be considered a violation of this prohibition. One does not have the right to diminish the ability of another person to make a fair and honest evaluation, whether in business or interpersonal relations.

Geneivat da'at applies even in situations in which there is no loss of money (Friedman, 2002) and even in interpersonal situations that do not involve money at all (any kind of undeserved 
goodwill could be a violation of geneivat da'at). Thus, offering a gift to another person knowing that the latter will not accept it or urging a friend to join one for a meal knowing that he will refuse (e.g., he already ate) is also geneivat da'at (Babylonian Talmud, Chullin 94a).

A retailer is not permitted to sprinkle his store with high-quality, fragrant wine in order to fool customers into believing that all the wine sold in the store is of the same superior quality (Tosefta, Bava Metzia 3:15). The Talmud describes other cases involving prohibited deception: painting animals or utensils in order to fool prospective buyers into thinking they are younger or newer; deceiving potential customers by placing the better quality merchandise on top of the bin (and the lower quality merchandise on the bottom) in order to make it appear that the merchandise is of uniformly high quality throughout; making an animal appear fatter than it really is by feeding it bran broth; and soaking meat in water to make it appear of superior quality (Babylonian Talmud, Bava Metzia 60a-b).

Jewish law requires that the seller inform the buyer of any hidden defects, deficiencies, shortcomings, or imperfections in their merchandise (Friedman, 2002; Levine, 1980: 117). Levine (1980: 117) observes: "Disclosure responsibility extends even to a flaw whose presence does not depreciate the article sufficiently to allow the vendee a price-fraud claim." Sales made under false pretenses, for example by hiding a product defect, would thus be null and void. Levine (1987: 89) asserts: “Conveying a false impression (geneivat da'at) by means of word or action is strictly prohibited... Proper disclosure requires the seller to divulge to his prospective buyer all defects in his product which are not visibly evident." 
Jewish laws dealing with fraud are based on the verse in Leviticus (25:14): "When you sell anything to your neighbor, or buy from your neighbor, you shall not wrong one another." Ona'ah (literally, oppression) is the term used by the Talmud to describe price fraud. Both overcharging and underpaying for a product is prohibited by Jewish law. In essence, the party with the upper hand (usually the seller, but sometimes the buyer) is not permitted to take advantage of the weaker party. The principle of caveat emptor (let the buyer beware) is not accepted by Jewish law.

There are situations in which a transaction made in error may be nullified by the court. For example, if the purchaser of the product has overpaid by more than one-sixth, the buyer has recourse to the courts and the sale may be nullified (Babylonian Talmud, Bava Metzia 49b). The one-sixth rule of ona'ah is essentially for movables and does not apply to real estate (it is difficult to establish a "fair" price for land), notes or IOUs (which are often sold at reduced prices with the buyer of the note collecting the money owed from the debtor who issued the note), and sacred objects sold by Temple overseers (Bava Metzia 56a). Even in cases where the rules of ona'ah do not nullify the sale, it is of course still prohibited to purposely deceive customers regarding the quality of good being sold.

The Maharsha (Babylonian Talmud, Chullin 94a) discusses the Talmudic dictum that one should not sell shoes made from the hide of an animal that died and claim that it came from an animal that was slaughtered (the latter hide is considerably stronger). He notes that the above misrepresentation would be a problem of ona'ah (price fraud, i.e., overcharging), since the hides from a slaughtered animal are of better quality and cost more than hides from animals that died. 
He therefore explains the Talmud as referring to a case in which the shoes were sold at a fair price. The seller, however, misrepresented the transaction and told the buyer that the shoes were made from hide that was from a slaughtered animal. There is no ona'ah because the price is reasonable; however, the seller has earned undeserved gratitude from the buyer who believes that he has received a bargain. This is why sellers are obligated to reveal any defect in a product, even if they intend to sell the product at a fair price that takes the imperfection into account.

One classic case involving deception in selling discussed in the Talmud (Babylonian Talmud, Bava Kama 46a) involves an individual who buys an ox and then finds out that the ox is wild, prone to goring others, and thus unsuitable for plowing. The seller claims that he sold the ox for meat so that the unsuitability of the ox for plowing is of no relevance. What does the Talmud conclude in this case? As long as a merchant sells only one type of product (e.g. oxen for plowing), and is clearly trying to deceive a blameless customer, there is no question that this is a violation of Jewish law. One is not permitted to deceive others, period. Full disclosure is always required by Jewish law and any type of deception or dishonesty falls under the Biblical prohibition (Leviticus 19: 1-13) against stealing, denying falsely, or lying.

Providing investors with bad advice and urging them to buy substandard securities violates both geneivat da'at and lifnei iver. Selling securities that are of dubious quality and pretending that they are investment grade is very similar to the case of the person who paints used merchandise to make it appear as new. This is not only forbidden but Jewish law would require the seller to refund the money. During the past several years, the toxic mortgages described above were bundled together into securities - collaterized debt obligations - so they could be sold to others. 
Normally, the way to reduce risk is to bundle together securities that have different kinds of risk, e.g., bonds from corporations in different industries. Here the risk was all the same: subprime mortgage loans given to low-income people with little chance of being able to pay the loans down the road. There was only one way that the price of the securities would not crash and cause a major catastrophe, and this required the housing bubble to continue indefinitely. Unfortunately - and entirely predictably - there was no way in the world that the prices of housing would continue to double every several years. The bundlers working for the investment banks were aware that the securities they were creating were extremely risky; however, they were making far too much money on them. Moreover, it was going to be someone else's problem since the securities (thanks to undeserved high ratings from the credit rating agencies) were being sold to unsuspecting investors all over the world. Countries and banks all over the world are in crisis mode today as a result of those financial shenanigans (Goodspeed, 2009).

There were a number of signs when the housing bubble was coming to an end, but no one cared - not the mortgage brokers, not the banks, not the bundlers, not (as we will see) the credit rating agencies. They were all making too much money. In fact, banks were encouraging mortgage brokers to find even more people who wished to become first-time property owners, and sell even more subprime mortgages. These mortgage brokers as did not reveal to prospective borrowers the danger of the loans to which they were being steered. The mortgage-backed securities that were sold to banks, pension funds, and other unsuspecting buyers are dragging down the entire world economy. Plans that have been suggested to save the American economy require that someone come along (government or private investors subsidized by the government) and pay “cash for trash." Clearly, few investors today believe that these securities 
are much better than trash. This was the "trash" sold to banks, pension plans, foreign governments, and investors all over the world. Undoubtedly, these investors were not told that they were purchasing junk.

\section{BRIBERY, OUTRIGHT AND SUBTLE}

The Torah is very strict about taking bribes: It states (Exodus 23: 8; Deuteronomy 16:19): "Do not accept a bribe" (shochad, in Hebrew) and (Deuteronomy 16:19): "Do not pervert judgment." The Talmud (Babylonian Talmud, Kethuboth 105a) adds that the Torah prohibits a judge from taking money even in order to acquit the innocent or to declare the guilty liable. To elaborate on this point, the Talmud (Babylonian Talmud, Kethuboth 105b) tells the story of Rabbi Yishmael son of Rabbi Yosi whose sharecropper brought him a basket of a fruit (from Rabbi Yishmael's

own orchard) every Friday afternoon. One day he brought the basket on Thursday. When Rabbi Yishmael asked him why he brought the fruit early, he was informed that the sharecropper wanted to use him as a judge on a case. Rabbi Yishmael recused himself and found others to try the case. Later, when Rabbi Yishmael overheard the proceedings, he kept thinking to himself of arguments the sharecropper might use to win the case. When he realized what he was doing, he cursed those who take bribes. He said that in this situation, where he did not take the gift and even if he had, it was fruit from his own orchard, yet, he was still biased and could not think clearly. All the more so, one who takes a bribe (or who even has a conflict of interest) can never be impartial. 
The Talmud (Babylonian Talmud, Kethuboth 105b) discusses a category of bribe known as shochad devarim (lit. "bribe of words" or "bribe of acts"). Several examples of shochad devarim, including the above-mentioned story of Rabbi Yishmael son of Rabbi Yosi, are provided. The sage Shmuel was crossing a bridge and a person gave him a helping hand. It turned out that this person needed a judge and Shmuel disqualified himself. Ameimar disqualified himself from serving as a judge because an individual who needed his services had removed a feather that had fallen on his head. Mar Ukva disqualified himself because someone covered up some spit that he was about to come across. It is obvious that Jewish law insists that justice must be completely unprejudiced and objective. Thus, a bias that arises from a past favor would very likely be shochad devarim. In fact, judges who are accustomed to borrow from the people living in their town and who do not have enough possessions to reciprocate should recuse themselves from judging people in their neighborhood (Babylonian Talmud, Kethuboth 105b). Individuals that have a need to borrow utensils and/or animals to maintain their own household become beholden to others and therefore lose their objectivity.

The Federal government is supposed to protect the public from fraud and predatory practices of the nature we discuss in this paper. What happened? The big question is what happened to all the regulations that were in place to protect the public. The answer is that the politicians worked together with the financial industry to remove most of these regulations.

In theory, House ethics rules make it unlawful for a member of congress to seek anything of value from a company or individual who has business interests before his/her committee. In practice, the entire political process is built on political contributions that come from 
industries and companies with an agenda. The lobbyists make it very difficult for legislators to behave in an objective way. In fact, this incestuous relationship between Congress and the financial industry helped contribute to the removal of regulations that caused the financial meltdown. One would assume that Shmuel, the Talmudic sage who disqualified himself for acting as a judge because someone gave him a helping hand, would certainly have disqualified himself for voting on legislation after receiving millions in political contributions. The following are just a few examples of how legislators may have been influenced by the lobbyists.

Phil Gramm, the former senator, a major proponent of deregulation, received huge amounts of contributions from the financial industry. From 1989 to 2002, he was the number one recipient of donations from commercial banks and among the major recipients of Wall Street campaign contributions. When he left the senate, he joined UBS as a senior investment banker and lobbyist: he headed the firm's lobbying operation in Washington (Lipton and Labaton, 2008). Ironically, UBS lost approximately $\$ 50$ billion thanks to the credit default swaps, a market that Phil Gramm helped make totally opaque with no government oversight (Lipton and Labaton, 2008).

Senator Charles Schumer, a member of the Banking and Finance Committee, has received significant amounts of money as contributions from Wall Street. Schumer is also known as the Democratic senator who has done more than any other democrat in embracing Wall Street's deregulatory, free market agenda (Lipton and Hernandez, 2008). He has been accused by John C. Bogle, founder of the Vanguard Group, of "serving the parochial interest of a very small group of financial people, bankers, investment bankers, fund managers, private equity firms, 
rather than serving the general public. It has hurt the American investor first and the average American taxpayer" (Lipton and Hernandez, 2008). Schumer succeeded in the following: "limiting efforts to regulate credit-rating agencies... sponsored legislation that cut fees paid by Wall Street firms to finance government oversight, pushed to allow banks to have lower capital reserves and called for the revision of regulations to make corporations' balance sheets more transparent" (Lipton and Hernandez, 2008).

In 2004, mortgage bankers and brokers pumped almost $\$ 847,000$ into the re-election campaign of President Bush. One of the major donors to the Republican Party in 2004 was Roland Arnall, founder of Ameriquest Mortgage Corp, which at one time was the country's largest subprime lender (Becker, Stolberg, and Labaton, 2008). In this regard, many of our "public servants" are guilty of geneivat da'at, shochad devarim, and conflict of interest - a perfect trifecta!

The financial debacle could not have occurred if the regulators such as the S.E.C. and the Federal Reserve were doing their job. A number of state attorneys general recognized that the type of loans being made to the poor were dishonest. Some did try to stop these predatory loans, but they were trumped by Federal law. What happened? Bribery, whether outright or subtle (i.e., shochad devarim) was definitely one of the problems here.

The problem continues and hedge funds are using their money to do everything possible to influence politicians not to increase oversight and transparency in their industry. Political donations by the hedge fund industry have increased $200 \%$ from 2006 . Last year, approximately \$17 million was distributed to key politicians (Reid, Schumer, Gillibrand, Dodd, 
etc.); the industry has also spent $\$ 15$ million on lobbyists. A key person is former congressman Richard H. Baker who now heads Managed Funds Association, the primary lobbying group for the hedge fund industry (Story, 2009).

\section{HONEST WEIGHTS AND MEASURES}

The Hebrew Bible is very concerned with honest weights and measures. Scripture states (Leviticus 19: 35-36): "You shall not commit an unrighteousness in justice, in measures of length, weight, or volume. Just scales, just weights, just dry measures, and just liquid measures you shall have." One is not permitted to own an inaccurate weight or measure (Deuteronomy 25: 13-15): "you shall not have in your pouch a stone-weight and a stone-weight - a large one and a small one [used as a counterbalance on a scale]. You shall not have in your house a measure and a measure - a large one and a small one. A perfect and honest stone-weight shall you have; a perfect and honest measure shall you have." The conclusion of the verse calls dishonest weights and measures "abominations to God." This is why shopkeepers were instructed to wipe their weights once a week and clean their scales after every weighing (Babylonian Talmud, Bava Bathra 88a). In addition, market commissioners were appointed to oversee businesses using weights and measures (Babylonian Talmud, Bava Bathra 89a).

In our society, credit ratings are the modern equivalent of the stone-weight, and auditors are the market commissioners. Providing dishonest measures is an abomination. In the past, the credit rating agencies such as Moody's and Standard \& Poor did not take money from the issuer of the 
debt instrument for the provided ratings. It was obvious that doing so would be a conflict of interest; the fear was that the issuer of the security was paying to get higher ratings. Investors, who purchased the publications of the credit-rating agencies, were the one who paid (Morgenson, 2008). This all changed in the early 1970s when the credit-rating agencies starting charging fees for their ratings. Indeed, there are a number of scholars who feel that there should be a law prohibiting issuers of securities for paying for the ratings (Lewis and Einhorn, 2009).

The credit rating agencies rated "trash" securities as high-quality and investment grade so there would be a market for them. The rating agencies made very healthy profits on the ratings, so they were not at all impartial (discussed further, under conflict of interest). All have been accused of being overly generous in how they rated the securities that basically consisted of bundled, low-quality subprime mortgages. The big question is whether these firms assigned very good ratings because of sheer incompetence or in a deliberate bid to make more money. By ingratiating themselves with clients, these agencies were able to steer more business their own way, and it is clear that the firms were able to make considerably more by providing ratings for complex financial securities than for simple bonds.

It is now evident that there were serious problems with the ratings. Companies such as AIG, Fannie Mae, Freddie Mac, GE, and MBIA kept their AAA ratings for a very long time and were not downgraded even when it was obvious that they had taken on too much risk (Lewis and Einhorn, 2009). Segal (2009), in asserting that the fees given to the agencies influenced them, says: "The agencies put their seals of approval on countless subprime mortgage-related securities now commonly described as toxic... At least 10 of the big companies that failed or 
were bailed out in the last year had investment grade ratings when they went belly up - like deathly ill patients bearing clean bills of health." Morgenson (2008) quotes a managing director at Moody's, a firm that rates the quality of bonds: "These errors make us look either incompetent at credit analysis or like we sold our soul to the devil for revenue, or a little of both.”

Credit rating agencies that provided deceptive ratings are also guilty of geneivat da'at as well as lifnei iver. Needless to say, the undeserved high ratings given to extremely risky firms and securities have caused the entire financial system to "stumble."

\section{CONFLICT OF INTEREST}

The Talmud (Babylonian Talmud, Baba Metzia 38a) discusses a disagreement regarding the law in the case of a bailee who is watching someone's fruit, wine, oil, or honey and notices that it is starting to spoil. Should he sell it or is he not permitted to do anything? The Sages (majority view) maintain that he should sell it to others under the supervision of the court, but he is not permitted to buy it for himself. The reason is that we do not want people to suspect that the bailee purchased it for an unfairly low price. Klainman (2000) uses this law to prove that the Jewish laws dealing with conflict of interest are not only for judges, witnesses, or public officials. These laws are also for trustees or "anyone having a fiduciary relationship with another." 
Another problem with conflicts of interest in Jewish law is that they are conceptually close to the idea of taking a bribe (Sefer Emunah U'Betachon 3:30), as we saw in the section on bribery. Also, they cause others to be suspicious of one's motives, implying a lack of transparency or oversight. As noted in the next section, one is obligated to act in a way that does not cause others to be suspicious of one's actions. There is no question that Jewish law does not allow people or organizations to place themselves in a situation where a conflict of interest is present.

The Talmud (Babylonian Talmud, Sanhedrin 18b) states that neither the king nor the High Priest may be members of the court that is involved in the intercalation of the year. The Jewish calendar requires the addition of a month (Adar Sheni) when the rabbis deemed it necessary and some years have 12 lunar months and some have 13 lunar months. The king is not permitted to be part of this court because of afsanya (maintenance of the army) and the High Priest because of the cold. The fear is that the king may prefer a leap year if he pays soldiers by the year (some commentaries interpret this passage to mean that the king will be reluctant to add a month if he pays the soldiers by the month). The Talmud felt that the conflict of interest was too great and therefore did not allow the king to participate as a member of the panel. The High Priest also had a conflict of interest. If he agreed to add another month, the following Yom Kippur would be later in the year when it is colder in Israel. This would result in a great deal of discomfort for him, either because of the five ritual baths he took on Yom Kippur and/or because the floor would be very cold and he performed the service barefoot. When it comes to conflicts of interest, no one is to be trusted. 
It is almost impossible to be objective when one receives financial remuneration. Thus, the Talmud states (Babylonian Talmud, Bechoros 28b-29a) that if one is paid to examine firstborn cattle in order to determine whether a blemish is permanent or not (if a blemish is permanent, the firstborn becomes the property of the priest and he may slaughter it and anyone may eat it; if it is temporary, then the cattle becomes sacred and must be slaughtered in the Temple as a sacrifice. Of course, the priest would prefer that the blemish be declared permanent.), we do not slaughter the cattle on his say-so unless he is an expert of the caliber [and piety] of Ila of Jabneh. The sages permitted Ila to charge four issarot for small cattle and six for large cattle; and whether he found the cattle to be permanently blemished or not, he received full payment. Another Mishna (Negaim 2:5) says that a priest may not examine his own cattle for a blemish. The reason is because of the conflict of interest and we suspect that the priest will be biased and not perform a good examination.

Politicians receiving political contributions from financial institutions should not have been voting on regulations regarding that industry. The credit rating agencies that rated the securities of firms that were paying them directly were also involved in a conflict of interest. A more subtle conflict of interest - and a lack of transparency - that has made it difficult for the S.E.C. to do its job properly is that regulators often go to work for Wall Street after working at the S.E.C. It is difficult to be tough on a firm that one expects to work for in the future. A job at the S.E.C. can be seen as one that provides valuable experience for one's next job on Wall Street and at a much higher salary. Thus, the S.E.C.'s previous director of enforcement is currently general counsel at JPMorgan Chase; the enforcement chief before him works for Deutsche Bank; and so on (Lewis and Einhorn, 2009). 
The biggest conflict of interest may have been a result of how Wall Street compensated executives. Cohan (2008) sees "Wall Street's bloated and ineffective compensation system" as a key cause of the financial meltdown. Cohan feels that the change of the old system where the big firms (e.g., Donaldson, Lufkin, and Jenrette; Merrill Lynch; Morgan Stanley; Goldman Sachs; Lazard; etc.) switched from being a partnership to a public company contributed to the financial debacle. When these firms were partnerships, there was collective liability so the firms were much more cautious. Once they became corporations with common stock, "bankers and traders were encouraged to take short-term risks with shareholder's money.” These bankers and traders did not mind taking on more and more risk since their bonuses depended on annual profits. Bonuses made up a huge part of how people were compensated.

One individual at Merrill Lynch received $\$ 350,000$ as salary but $\$ 35,000,000$ as bonus pay. Bonuses were based on short-term profits; this distorted the way incentives work. Employees were encouraged to take huge risks since they were interested in the bonus which were based on the earnings for that year. Thus, billions in bonuses were handed out by Merrill Lynch in 2006 when profits hit $\$ 7.5$ billion. Of course, those profits were an illusion and were based on toxic mortgages. After that, the company lost triple that amount; the bonuses were not rescinded (Story, 2008). Lucian Bebchuk, a compensation expert, asserted that "the whole organization was responding to distorted incentives" (Story, 2008). Put these ingredients together encourage risk taking, no accountability, and use shareholder's money - and you get a financial meltdown. 
In fact, according to the Center for Responsible Lending (2008), in the first four years of a mortgage, subprime borrowers who used a mortgage broker paid \$5,222 more than individuals who went directly to lenders and did not use brokers. Mortgage brokers earned a yield-spread premium by convincing borrowers to take on a more expensive mortgage at a higher rate of interest rather than a cheaper mortgage. In effect, yield spread premiums are kickbacks from the bank to the broker for convincing the borrowers to agree to more expensive mortgages.

Mortgage brokers were supposed to be working for clients and finding them the cheapest mortgages. Unfortunately for clients, the conflict of interest was too tempting for most of the mortgage brokers. They had a choice: finding clients cheap mortgages and earning considerably less or steer clients to expensive mortgages and earn a yield-spread premium, i.e., a nice kickback from the bank. Needless to say, most mortgage brokers opted for the latter choice. Unfortunately, greed usually beats out honesty. The ancient Talmudists knew this, hence the emphasis on avoiding conflicts of interest, subtle - even unintended - bribery, and the appearance of impropriety.

\section{TRANSPARENCY}

The Bible states (Numbers 32:22): “and you shall be innocent before God and Israel." This verse is used by the Talmud to derive the principle that one is obligated to behave in such a manner that $\mathrm{s} /$ he does not give rise to suspicions on the part of others. Conflicts of interest, of course, cause people to be suspicious of one's actions and this is not permitted. Demonstrating 
the importance of keeping honest records, Scripture (Exodus 38:21-31) enumerates the amount of gold, silver, and copper used in the construction of the Tabernacle. Moreover, the Bible (Exodus 38:21) informs us who was ultimately responsible for guaranteeing that accurate records were kept: "These are the accounts of the Tabernacle, the Tabernacle of the Testimony, as they were calculated according to the commandment of Moses..." Moses wanted to show everyone that he was acting in such a way so that no one would be suspicious of him and to make evident to the Israelites that no precious metals were diverted for anyone's personal use. Thus, he commanded others to audit the books. Today we would refer to this as transparent accounting records. The Midrash (Exodus Rabbah 51:1) comments: "though Moses was the sole treasurer, yet he called others to audit the accounts with him."

The Talmud (Babylonian Talmud, Pesachim 13a) states that the overseers in charge of the soup kitchen were not allowed to purchase surplus food when there were no poor people for whom to distribute it. Surpluses were only allowed to be sold to others so as not to arouse suspicion that the charity overseers were profiting from public funds. The Talmud (Babylonian Talmud, Yuma 38) relates how the family of Garmu, that made the showbread for the Temple, was especially careful to be above suspicion. Their children were never seen with fine bread. Brides from the family of Abtimas never wore perfume since this family made the incense for the Temple.

Numerous parties that helped cause the financial meltdown did not act in a transparent, aboveboard manner. It is first now becoming more obvious why bankers, for example, were not doing their jobs properly. Traditionally, banks were among the most conservative of industries. 
Outsiders did not know they themselves referred to their toxic mortgages as, say, "Liar Loans". No one thought to ask. Where were the auditors?

$\mathrm{WaMu}$, one of the banks very much involved in providing mortgage loans to almost everyone who walked through the door had a good reason for doing this. Kerry K. Killinger, CEO of WaMu, put a huge amount of pressure on employees to lend money to borrowers with little in the way of income or assets. Loan officers were encouraged to approve mortgages with virtually no checking of income. Real estate agents were given fees of thousands of dollars for bringing borrowers to WaMu. WaMu also gave mortgage brokers generous commissions for the riskiest loans since they produced higher fees and resulted in increased compensation for executives. To encourage people with little income to borrow money, WaMu used option ARMs (Adjustable Rate Mortgages). This enticed people to take out mortgages because of very low initial rates. Of course, many borrowers mistakenly thought the low payments would continue indefinitely and would never balloon (Goodman and Morgenson, 2008). The number of ARMs at WaMu increased from $25 \%$ in 2003 to $70 \%$ in 2006 . It did not take long for word to spread that WaMu would give mortgages to nearly anyone. It is no coincidence that between 2001 and 2007, CEO Killinger earned approximately \$88 million (Goodman and Morgenson, 2008).

In a nutshell, banks were overleveraged, i.e., took on a huge amount of debt relative to equity. They undertook a great deal of risk rather than lending depositors' money in a prudent manner. They did all this because they were interested in the bonuses they could make each year. Then, the banks found themselves holding toxic assets whose true value is almost impossible to determine. Banks knew they were dealing with garbage. People did not know how toxic the 
mortgages were. The most conservative - and heretofore, trustworthy - of industries embraced risk behind opaque financial instruments.

Credit Default Swaps (CDS) were originally developed to insure bond investors against default risk but they took on a life of their own and were been used for speculation purposes. A CDS is a credit derivative and resembles insurance since the buyer makes regular payments and collects if the underlying financial instrument defaults. In a CDS, there is the protection buyer who can use this instrument for credit protection; the protection seller who gives the credit protection; and the specific bond or loan that could go bankrupt or into default is the "reference entity." It could be compared to buying fire insurance on someone else's house. It was unregulated thanks to the politicians who were "encouraged" by the financial industry and at some point it went out of control. The executives were making a huge amount of money on them since they could collect premiums from many different investors on the same underlying security (imagine being able to sell fire insurance to thousands of speculators on one particular house; as long as the house does not burn down, you can make a great deal of money).

Since one did not actually have to own the security ("reference entity') to buy the CDS that is on it, this meant anyone could bet that the security will default. This is how it became possible for the CDS market to become so large - many times larger than the total amount of corporate debt. Buying a CDS can actually be riskier than betting in Las Vegas. Virtually all casinos have sufficient money to cover a jackpot, even a big jackpot. Moreover, the casinos are regulated. Casinos that do not have sufficient money to payout in the event of a jackpot will be closed down. With CDS, many of the hedge funds selling the derivative had no problem collecting the 
fees but did not have the money to pay if there was indeed a default on the security. One assumes that many of the hedge funds felt that if something bad happened and they could not make the payments, they would go out of business. This was a business that was totally opaque and the hedge funds did what they wanted. Eric Dinallo, the insurance superintendent of New York State, compared this market to a "bookie operation" and "legalized gambling" (Kroft, 2008):

When banks can engage in gambling and it is not clear that's what they are doing until the system crashes, there's a lack of transparency. SEC Chairman Christopher Cox stated that it is now of utmost importance to bring transparency to the unregulated market in CDS. According to Landy (2008), no one even knows the exact size of the CDS market; estimates range from $\$ 35$ trillion to $\$ 55$ trillion. They played a major role in the financial meltdown and were also the cause of the near bankruptcy of A.I.G. which necessitated a government bailout (Landy, 2008; Cox, 2008). When A.I.G. was bailed out by the Federal government it held $\$ 440$ billion of CDSs (Philips, 2008). Of course, A.I.G. offered these instruments and did not have the reserves to cover them if anything went wrong and the housing market crashed. Why was this done? The very high bonuses gave managers an incentive to throw caution to the wind and take huge risks with other people's money.

\section{CONCLUSION}

This paper reviewed the financial meltdown of 2008 from the perspective of Jewish law using 
six framing principles: misleading with bad advice; deception and fraud; bribery, both outright and subtle; honest weights and measures; conflicts of interest; and, finally, transparency. Over the course of this review it became clear that these six principles are not absolutely discrete. Rather, there is quite a bit of overlap, with boundaries that are elastic and permeable as one blends into the next. In addition, many of the behaviors described in this paper violate multiple principles, and we sometimes could not separate them neatly and easily into discrete violations according to the sections of this paper. Thousands of years ago, it was known that aveira goreret aveira, that is, one transgression causes another, which causes another, which causes a cascade of others. Indeed, one scholar, in discussing the Ten Commandments, answered the question of why Lo Tachmod ("You shall not covet...") is last. After all, it is only coveting, doesn't seem to require much in the way of action. Why is it in so important a position on the list of Ten? This is because when you engage in coveting - greed and lust (itself a manifestation of greed) - a violation of the tenth commandment, you often end up violating the other nine as well (Avi Ezer, Exodus 20:14).

A recurrent theme in this review is that while U.S. law allowed, ignored, and even encouraged the fraudulent, misleading, and opaque activities that led to the current economic collapse. Jewish law takes a different view of much of what happened. Scholars from both the Orthodox and Conservative branches of Judaism have noted that the global financial crisis would not have occurred had the business ethics principles discussed in the Talmud and the Torah been observed; Jewish law was violated at every step of the way to the current financial disaster (Biema, 2008). Jewish law is tied to ethics and insists that individuals go beyond the mere letter of the law. It is obvious that the current financial crisis could not have occurred had various 
parties, ranging from mortgage bankers to regulators, obeyed Jewish law. Indeed, the parties involved in the financial meltdown did not even abide by the minimum standards of Jewish law.

The prophet Jeremiah (22:13) excoriated those who did not care about honesty and justice; in his words: "Woe to him who builds his house with unrighteousness and his upper stories with injustice." The cause for this is (Jeremiah 22:17): "But your eyes and your heart are only on your dishonest gain." The current financial crisis is due to greed. Had the bankers, auditors, rating agencies, politicians, regulators, and mortgage brokers followed the principles of business ethics described in Jewish law, the financial meltdown - really, more of a values meltdown - would not have occurred. 


\section{REFERENCES}

Becker, J., Stolberg, S. G. and Labaton, S. (2008, December 21). White House philosophy stoked mortgage bonfire. New York Times, 1, 36-37.

Biema, D. V. (2008, October 10). The financial crisis: What would the Talmud do? Time, Retrieved April 13, 2009 from http://www.time.com/time/business/article/0,8599,1849231-1,00.html

Center for Responsible Lending (2008, April 8). Subprime borrowers needlessly overpaid for brokered mortgages. Retrieved from http://www.responsiblelending.org/press/releases/subprime-borrowers-needlesslyoverpaid-for-brokered-mortgages.html on April 11, 2009

Cohan, W. D. (2008, November 16). Our risk, Wall Street's reward. New York Times, Week in Review, 13.

Cox, C. (2008, October 19). Swapping secrecy for transparency. New York Times, Week in Review, 12.

Friedman, H. H. (1985). Ethical behavior in business: A hierarchical approach from the Talmud, Journal of Business Ethics, 4, 117-129.

Friedman, H. H. (2002). Geneivat da'at: The prohibition against deception in today's world. Jewish Law. Retrieved April 13, 2009 from http://www.jlaw.com/Articles/geneivatdaat.html

Goodman, P. S. and Morgenson, G. (2008, December 28). By saying yes, WaMu built empire on shaky loans. New York Times, 1, 22.

Goodspeed, P. (2009, March 13). Global mess gives birth to new era. National Post, Retrieved March 30, 2009 from http://www2.canada.com/topics/news/story.html?id=1387642

Klainman, R. (2000). Conflicts of interest of public officials in Jewish law - Prohibitions, scope, and limitations." In H.G. Sprecher, ed., Jewish Law Association Studies X: The Jerusalem 1998 Conference Volume, pp. 93 - 116, Binghamton NY: Global Publications of SUNY at Binghamton.

Kroft, S. (2008, October 26). The bet that blew up Wall Street. 60 Minutes, retrieved January 4, 2008 from http://www.cbsnews.com/stories/2008/10/26/60minutes/main4546199.shtml

Landy, H. (2008, November 15). Credit default swaps oversight nears. Washington Post, D03.

Levine, A. (1987). Economics \& Jewish law: Halachic perspectives. New York: Ktav Publishing House/Yeshiva University Press.

Levine, A. (1980). Free enterprise and Jewish law. New York: Ktav Publishing House/Yeshiva University Press. 
Lewis, M. and Einhorn, D. (2009, January 4). The end of the financial world as we know it. New York Times. Week in Review, 9-10.

Lipton, E. and Hernandez, R. (2008, December 14). A champion of Wall Street reaps benefits." New York Times, 1, 36.

Lipton, E, and Labaton, S. (2008, November 17). Deregulator looks back unswayed. New York Times, Retrieved January 11, 2009 from http://www.nytimes.com/2008/11/17/business/economy/17gramm.html?_r=1\&fta=y\&pa gewanted=print.

Morgenson, G. (2008, December 7). Debt watchdogs: Tamed or caught napping. New York Times, 1, 40.

Pava, M. L.(1997). Business ethics: A Jewish perspective. New York: Ktav Publishing House/Yeshiva University Press.

Philips, M. (2008, October 6). The monster that ate Wall Street. Newsweek. Retrieved on January 4, 2009 from http://www.newsweek.com/id/161199

Segal, D. (2009, March 18). The silence of the oracle. New York Times, B1, B5.

Story, L. (2008, December 18). On Wall Street, bonuses, not profits, were real. New York Times, A1, A35.

Story, L. (2009, June 23). Hedge funds step up efforts to avert tougher rules. New York Times, B3.

Tamari, M. (1991). In the marketplace. Southfield, MI: Targum Press. 